Volume 4 No 2 Maret 2019

p-ISSN : 2460-8750 e-ISSN : 2615-1731

http://dx.doi.org/10.26858/talenta.v4i2.7618

\title{
PERAN KEGIGIHAN DALAM HUBUNGAN GROWTH MINDSET DAN SCHOOL WELL-BEING SISWA SEKOLAH MENENGAH
}

\author{
Fatin Rohmah Wahidah ${ }^{1}$ Lucia R.M Royanto ${ }^{2}$ \\ Fakultas Psikologi, Universitas Indonesia. Indonesia \\ Email: fatin.nw@gmail.com ${ }^{1}$ hereslucy02@gmail.com²
}

\begin{abstract}
Abstrack. This study investigates the relationship between school well-being, growth mindset, and grit. The subjects involved in this study are students from grade 12 in high public and private schools in Purbalingga, Central Java (n=418). The research method used is quantitative method with data collection through three questionnaires, i.e., School Well-Being Scale (32 items, $\alpha=0.853$ ); Mindset Scale (20 items, $\alpha=0.804$ ); and Grit Scale for Children and Adult (12 items, $\alpha=0.774)$. Results indicated a positive affact growth mindset on school well-being, a positive affact growth mindset on grit, and confirmed the mediating role of grit. It was concluded that the effect of growth mindset on school wellbeing of senior high school students in Purbalingga was mediated by grit. Growth mindset in students predicts higher school well-being through the enhancement of grit. Thus, giving intervention of growth mindset and grit can be carried out by school to improve students's school well-being.
\end{abstract}

Keywords : grit, growth mindset, high schools, school well-being

Abstrak. Tujuan dari penelitian ini adalah untuk mengetahui hubungan school well-being, growth mindset, dan kegigihan. Partisipan yang terlibat adalah siswa kelas 12 sekolah menangah atas dari sekolah negeri dan sekolah swasta di daerah Purbalingga, Jawa Tengah $(\mathrm{n}=418)$. Metode penelitian yang digunakan adalah metode kuantitatif dengan pengumpulan data melalui tiga kuesioner, yaitu skala School Well-Being (32 aitem, $\alpha=0.853$ ); skala Mindset (20 aitem, $\alpha=0.804)$; and Grit Scale for Children and Adult (12 aitem, $\alpha=0.774$ ). Hasil penelitian menunjukkan adanya pengaruh positif growth mindset terhadap school wellbeing, pengaruh positif growth mindset terhadap kegigihan, dan kegigihan terkonfirmasi sebagai mediator. Dapat disimpulkan, pengaruh growth mindset terhadap school well-being pada siswa sekolah menengah di Purbalingga dimediasi oleh kegigihan. Growth mindset pada siswa memprediksi school well-being, melalui pengembangan kegigihan. Oleh karena itu, pemberian intervensi dengan menyasar growth mindset dan kegigihan disarankan dapat dilakukan sekolah untuk meningkatkan school well-being siswa.

Kata Kunci: growth mindset,Kegigihan, school well-being, Sekolah Menengah atas

\section{PENDAHULUAN}

Pendidikan menjadi sarana dalam upaya peningkatan kualitas kehidupan masyarakat sebagaimana yang dicita-citakan bangsa
Indonesia dalam UUD 1945. Adapun penyelenggara satuan pendidikan yang bersifat formal dengan jenjang yang jelas disebut sekolah. Berdasarkan UU Sisdiknas 
134 I Jurnal Psikologi Talenta Vol. 4 No. 2

No 20 Tahun 2003, siswa di Indonesia umumnya akan menempuh pendidikan dasar selama 9 tahun, pendidikan menengah selama 3 tahun, dan pendidikan tinggi dalam rentang waktu yang bervariasi (satu hingga empat tahun, bahkan lebih). Selama bertahun-tahun menjalani pendidikan, siswa akan bertumbuh dan menghadapi tugas perkembangan yang tak lepas dari pengaruh lingkungan sekolahnya, termasuk melewati masa remaja. Masa remaja merupakan masa transisi terkait perubahan-perubahan yang terjadi secara fisik, psikologis, sosial, budaya, dan akademiknya. Pada tahap ini, individu mengalami masa-masa krusial karena dihadapkan dengan berbagai tantangan dalam penyesuaian diri terhadap tuntutan-tuntutan lingkungan yang ada (Bask \& Salmela-Aro, 2013).

Siswa berusia remaja umumnya berada di jenjang sekolah menengah (SMA/SMK/MA). Di sekolah, remaja menghabiskan bertahun-tahun waktunya sebagai bagian dari sebuah masyarakat kecil yang mempengaruhi perkembangan sosioemosionalnya melalui interaksi dengan guru dan teman sebaya yang berasal dari beragam latar belakang budaya dan ketertarikan (Santrock, 2011). Selain menghadapi masa krisis, remaja di sekolah menengah juga menghadapi beban tugas sekolah yang semakin besar terlebih pada siswa di tingkat akhir atau kelas 12. Siswa kelas 12 memiliki jam belajar yang paling banyak dan akan menjalani lebih banyak ujian dibanding kelas 10 atau11. Selain itu, kelas 12 pun mulai disibukkan dengan
Peran Kegigihan dalam Hubungan Growth Mindset

pemikiran dan persiapan berbagai hal terkait perencanaan karir di masa mendatang. Berbagai tantangan dan tuntutan tersebut dapat berpotensi memunculkan stres pada siswa kelas 12. Di sisi lain, kesehatan mental siswa tetap perlu diperhatikan.

Kesehatan mental menurut definisi dari World Health Organization (WHO) adalah kondisi well-being yang memungkinkan seseorang untuk mengoptimalkan potensinya, bekerja secara produktif, dan mampu berkontribusi pada lingkungan atau komunitasnya. Well-being mengacu pada kondisi individu atau sekelompok individu dalam domain yang khas, seperti fisik, sosial, ekonomi, psikologis, dan spiritual. Tingginya well-being berkaitan dengan pengalaman positif individu. Sementara rendahnya well-being berkaitan dengan pengalaman atau kejadian negatif pada individu (Shaari, Amar, Harun, \& Zainol, 2017).

Lingkungan sekolah disebut sebagai setting utama yang memiliki peran krusial dalam mewujudkan well-being siswa. Melalui iklim sekolah yang positif dan hubungan yang dekat serta adanya rasa memiliki pada sekolah berhubungan dengan sense of well-being, resiliensi, serta penyesuaian akademik dan sosial pada siswa (Evans, Martin, \& Ivcevic, 2018). Siswa yang memiliki well-being akan merasa sehat, nyaman, bahagia, berharga, dan sejahtera sehingga mereka akan cenderung memiliki penilaian yang positif terhadap sekolah, lebih menyukai sekolah, dapat belajar secara efektif, dan memberi kontribusi positif pada sekolah (Papalia, Olds, \& Feldman, 2009; Konu \& Rimpelä, 2002). Pada beberapa literatur, well-being di sekolah dikenal dengan istilah school well-being. 
School well-being didefinisikan sebagai penilaian subjektif siswa terhadap sekolah terkait pemenuhan kebutuhan dasar siswa meliputi kondisi sekolah (having), hubungan sosial (loving), pemenuhan diri (being), dan kesehatan (health) (Konu \& Rimpelä, 2002). Having merujuk aspek material dan non-material, seperti bentuk bangunan atau lingkungan fisik sekolah, hukuman yang diberikan, serta pelayanan yang ada di sekolah. Loving mengacu pada kebutuhan untuk menjalin hubungan dengan orang lain dan membentuk identitas sosial, misalnya bagaimana iklim sekolah, hubungan guru dan siswa, hubungan dengan teman sebaya, dan hubungan sekolah dengan orang tua (Konu \& Rimpelä, 2002).

Being mengacu pada kebutuhan akan pertumbuhan sosial, yaitu bagaimana cara sekolah memberikan kesempatan pada siswa untuk mendapat kesejahteraan atau pemenuhan diri. Hal ini dapat berupa kesempatan yang sama bagi seluruh siswa untuk menjadi bagian dari warga sekolah dan adanya kesempatan siswa untuk mengembangkan pengetahuan dan keterampilan berdasarkan minat siswa. Terakhir, health merujuk pada tidak adanya sumber penyakit dan siswa yang sakit, baik secara mental maupun fisik, serta penghayatan akan keadaan diri yang sehat (Konu \& Rimpelä, 2002).

Adanya model school well-being ini juga memungkinkan sekolah untuk mengetahui perspektif siswa atas pencapaian well-being di sekolah. Berdasarkan hal tersebut, sekolah dapat mengarahkan pendidikan, pengajaran, dan pembelajarannya sehingga dapat memenuhi kebutuhan dasar siswa untuk mengembangkan kepribadian dan bakat siswa, kemampuan fisik dan mental siswa, dan mengoptimalkan potensi yang dimiliki (Konu \& Rimpelä, 2002).

Merujuk pada penelitian terdahulu, ditemukan beberapa faktor internal maupun eksternal yang mempengaruhi well-being siswa. Faktor internal, diantaranya mindset (Zeng, Hou, \& Peng, 2016; Chan, 2012) dan kegigihan (Jin \& Kim, 2017). Sementara faktor eksternal, diantaranya dukungan guru dan teman (Wijayanti \& Sulistiobudi, 2018; Lester \& Cross, 2015) serta hubungan dengan orang tua (Lampropoulou, 2018). Hossaini, Boogar, dan Najafi (2017) berpendapat bahwa faktor internal lebih dapat mempengaruhi well-being siswa dibandingkan faktor eksternal. Oleh karena itu, penelitian ini akan lebih mempertimbangkan faktor internal sebagai pengaruh dari well-being.

Mengingat well-being merupakan sebuah penilaian subjektif dari individu, maka setiap orang dapat memberi reaksi yang berbeda pada setiap keadaan dan mengevaluasi kondisinya berdasarkan ekspektasi khas, nilai-nilai, dan pengalaman individu sebelumnya (Diener, Suh, Lucas, \& Smith, 1999). Artinya, terdapat seperangkat asumsi yang berperan membuat penilaian tersebut. Dalam konteks pendidikan, terdapat seperangkat asumsi yang telah ada terkait kualitas dasar individu yang dikenalkan oleh Dweck (2006) sebagai mindset.

Mindset menggambarkan karakteristik individu terkait cara pandang seseorang terhadap kemampuan dan inteligensinya, apakah cenderung menetap atau bisa berubah (Duckworth, 2016). Dweck membagi mindset menjadi dua jenis yaitu fixed mindset dan growth mindset. Seseorang yang percaya bahwa kemampuan, karakter, potensi dan inteligensi yang dimiliki bersifat bawaan, cenderung menetap, dan tidak dapat 
berubah disebut memiliki fixed mindset. Sebaliknya, seseorang yang percaya bahwa adanya usaha dan kontrol akan dapat mengembangkan kemampuan, karakter, potensi, dan inteligensinya karena hal tersebut dapat berubah disebut memiliki growth mindset (Dweck, 2006). Individu dengan fixed mindset percaya bahwa kecerdasan mereka merupakan sifat bawaan dengan sejumlah tertentu saja. Sebaliknya, individu dengan growth mindset percaya bahwa mereka dapat mengembangkan kecerdasan mereka dari waktu ke waktu (Hochanadel \& Finamore, 2015).

Remaja yang memandang dirinya memiliki growth mindset cenderung berpandangan lebih positif terhadap usahanya, lebih dapat mengatasi kesulitan dalam tugas dan lebih termotivasi pada situasi yang menantang, tidak hanya mendasarkan pada kemampuan yang dimiliki (Jach, Sun, Loton, Chin, \& Waters, 2017). Dengan demikian, mereka akan lebih positif dan memiliki strategi untuk lebih berusaha ketika menghadapi tantangan. Sebaliknya, remaja yang memiliki fixed mindset nampak kurang memiliki keyakinan yang positif terkait kapasitas diri dan menunjukkan kurangnya usaha dan capaian (Blackwell, Trzesniweski, \& Dweck, 2007). Selanjutnya, peneliti tertarik untuk mempelajari bagaimana pengaruh growth mindset terhadap school well-being.

Sejauh penelusuran peneliti, penelitian terkait growth mindset dan school wellbeing masih jarang dilakukan saat ini. Akan tetapi, terdapat model penelitian terkait growth mindset dan well-being sebelumnya yang dilakukan oleh Zeng, Hou, dan Peng (2016) terhadap 1260 siswa SD dan SMP di China. Hasilnya menunjukkan bahwa growth mindset mampu memprediksi tingkat well-being siswa melalui resiliensi. Siswa dengan growth mindset cenderung berpikir bahwa inteligensi dan kemampuannya dapat terus meningkat sehingga mereka terus berusaha menunjukkan performanya, tidak menyerah ketika menemui kesulitan dalam belajar maupun tugas akademik di sekolah. Melalui resiliensi yang dimiliki, siswa menjadi adaptif dan mampu menyelesaikan masalah tersebut sehingga memiliki well-being yang lebih baik dibanding siswa yang memiliki fixed mindset (Zeng, Hou, \& Peng, 2016).

Resiliensi merupakan kemampuan adaptasi seseorang untuk bertahan, memulihkan dan mengumpulkan kembali sumber daya yang dimiliki untuk menghadapi tekanan dan pengalaman negatif yang ditemui (Hossaini, Boogar, \& Najafi, 2017; Zeng, Hou, \& Peng, 2016). Salah satu konsep yang dikatakan mirip dengan resiliensi dan baru-baru ini menarik diteliti dalam dunia pendidikan adalah kegigihan. Keduanya merupakan konsep yang menjelaskan kemampuan seseorang untuk bertahan dalam situasi yang sulit (Stoffel \& Cain, 2018) dan merupakan trait kepribadian yang sama-sama dibutuhkan dalam menjaga well-being siswa (Zeng, Hou, \& Peng, 2016; Stoffel \& Cain, 2018). Akan tetapi jika dibandingkan, kegigihan melibatkan unsur tujuan dan menggambarkan komitmen usaha dalam waktu yang lama. Sementara resiliensi tidak melibatkan unsur tersebut dan secara umum lebih menekankan pada kemampuan seseorang untuk bangkit kembali dari pengalaman negatif atau menekan (Stoffel \& Cain, 2018), yang sementara. Lebih jauh, kegigihan dianggap sebagai faktor nonkognitif yang memprediksi kesuksesan siswa (Sturman \& Zappala-Piemme, 2017) karena ketahanannya dalam berusaha, meskipun menghadapi hambatan-hambatan dalam mencapai tujuan jangka panjangnya (Duckworth, 2016). Siswa yang gigih akan 
memperoleh kesuksesan karena berusaha keras menghadapi tantangan dan mempertahankan usaha guna mencapai tujuannya. Sebaliknya, siswa yang tidak gigih akan tidak berhasil memperoleh kesuksesan karena berhenti berusaha ketika menghadapi masalah atau kesulitan (Duckworth, 2016).

Bila ditinjau hubungan kegigihan dan growth mindset, Dweck (2006) menjelaskan bahwa siswa dengan growth mindset menganggap bahwa inteligensi dan kemampuan yang dimiliki adalah suatu hal yang bisa berubah sehingga lebih tekun dan fokus pada pembelajaran jangka panjang serta menghargai usaha yang dilakukan. Mereka juga akan lebih dapat mengatasi tugas dan lebih termotivasi ketika mengalami kondisi yang menantang (Dweck, Walton, \& Cohen, 2014; Chrisantiana \& Sembiring, 2017; RenaudDubé, Guay, Talbot, Taylor, \& Koestner, 2015; Jach, Sun, Chin, Loton, \& Waters, 2017). Artinya, siswa dengan growth mindset akan cenderung memiliki kegigihan.

Kegigihan selama ini banyak dijelaskan dalam hubungannya dengan performa akademik siswa (Duckworth, Peterson, Matthews, \& Kelly, 2007; Duckworth \& Quinn, 2009). Masih jarang studi yang mengkaji konstruk kegigihan dengan school well-being pada siswa. Salah satu penelitian yang membahas hubungan kegigihan dan well-being adalah studi dari Rosyadi dan Laksmiwati (2018) kepada mahasiswa di Surabaya. Menurut hasil studinya, kegigihan berhubungan positif dengan wellbeing. Semakin tinggi kegigihan yang dimiliki mahasiswa, semakin tinggi pula tingkat well-being yang dimiliki. Dalam studi yang dilakukan kepada remaja akhir dan dewasa muda di Istanbul Turki, Korea Selatan, dan Jaipur India ditemukan bahwa kegigihan berkontribusi pada well-being seseorang (Akbağ \& Ümmet, 2017; Jin \& Kim, 2017; Arya \& Lal, 2018). Orang yang gigih akan lebih dapat mencapai tujuannya dan memenuhi kebutuhan atau kepuasan dirinya sehingga ia memiliki well-being yang lebih tinggi (Jin \& Kim, 2017). Berkaitan dengan hal tersebut, tidak menutup kemungkinan bahwa school wellbeing siswa di sekolah juga dapat dipengaruhi oleh kegigihan ini. Siswa yang gigih akan berusaha keras menghadapi tantangan dan mempertahankan usaha guna mencapai tujuannya sehingga akan memiliki school well-being yang tinggi.

Berdasarkan penjelasan yang telah diuraikan, peneliti tertarik mengkaji lebih jauh peran kegigihan apakah dapat menjadi variabel mediator dalam hubungan antara mindset dan school well-being pada siswa sekolah menengah.

\section{METODE}

Metode penelitian kuantitatif dengan desain non-experimental study berupa cross sectional design. Metode yang digunakan peneliti dalam pengambilan sampel adalah non-probability sampling dengan teknik accicental sampling. Teknik ini dipilih karena mempertimbangkan kemudahan dalam pengambilan data dan ketersediaan waktu penelitian (Gravetter \& Forzano, 2011). Meski demikian, peneliti berusaha memperoleh sampel partisipan yang dianggap mewakili populasi melalui pemilihan perbedaan jenis kelamin, asal sekolah, jenis sekolah, reputasi sekolah, dan lokasi sekolah.

\section{Partisipan}

Jumlah partisipan dalam penelitian ini adalah 425 siswa, namun hanya 418 data partisipan yang dapat diolah karena tujuh 
138 I Jurnal Psikologi Talenta Vol. 4 No. 2

siswa lainnya tidak lengkap mengisi kuesioner. Partisipan adalah siswa kelas 12 tahun ajaran 2018/2019 yang berasal dari 8 sekolah (sekolah negeri, sekolah swasta, jenjang SMA/SMK/MA) di daerah Purbalingga, Jawa Tengah.

Instrumen

Alat ukur school well-being yang digunakan mengacu pada konsep Konu dan Rimpelä (2002), Instrumen untuk mengukur growth mindset merujuk pada teori mindset Dweck (2006). Untuk mengukur kegigihan, digunakan alat ukur Grit Scale for Children and Adult (GSCA) dari Sturman dan Zappala-Piemme (2017). Adapun nilai $\alpha$ Cronbach masing-masing alat ukur school well-being, growth mindset, dan kegigihan masing-masing adalah sebesar 0.853; 0.804; dan 0.774. Beberapa pertanyaan terkait demografi partisipan, seperti usia, jenis kelamin, dan latar belakang orang tua juga dimasukkan dalam kuesioner bersama ketiga alat ukur. Kemudian dianalisis menggunakan analisis deskriptif, korelasi Pearson, dan regresi. Partisipan terlebih dulu mengisi informed consent sebelum terlibat penelitian

\section{HASIL DAN PEMBAHASAN}

Sebagian besar partisipan berjenis kelamin perempuan $(64,35 \%)$ dan berusia 17 tahun $(73,40 \%)$. Mayoritas partisipan memiliki orang tua yang memiliki pendidikan terakhir yaitu pendidikan dasar (ayah 48,33\%; ibu 56,22\%). Kebanyakan ayah dari partisipan bekerja sebagai pedagang $(30,62 \%)$. Sementara ibu dari partisipan sebagiannya tidak bekerja (41,38\%).
Peran Kegigihan dalam Hubungan Growth Mindset

Gambaran umum partisipan penelitian disajikan pada tabel 1 .

Uji korelasi Pearson dilakukan untuk mengetahui hubungan ketiga variabel. Hasilnya mengkonfirmasi bahwa terdapat hubungan positif yang signifikan antara growth mindset dan school well-being ( $\mathrm{r}=$ $0.18 ; \mathrm{p}<0.01), \quad$ growth mindset dan kegigihan $(\mathrm{r}=0.39 ; \mathrm{p}<0.01)$, serta kegigihan dan school well-being $(\mathrm{r}=4.09 ; \mathrm{p}<0.01)$. Selanjutnya, dilakukan uji mediasi kegigihan melalui tiga tahap regresi sebagaimana disarankan Baron dan Kenny. Pada tahap pertama, diketahui bahwa growth mindset berpengaruh signifikan pada school well-being. Pada tahap kedua, diketahui growth mindset berpengaruh signifikan pada kegigihan. Terakhir, pada tahap ketiga diperoleh bahwa growth mindset dan kegigihan berpengaruh signifikan pada school well-being (Tabel 2). Terdapat penurunan besaran koefisien regresi yang mulanya 0.509 menjadi 0.073 . Artinya, kegigihan terkonfirmasi sebagai mediator dalam hubungan growth mindset terhadap school well-being. Selain itu, terdapat perubahan signifikansi pada koefisien jalur growth mindset dan school well-being, yang tadinya signifikan menjadi tidak signifikan. Artinya, hubungan antara growth mindset dan school well-being dimediasi oleh kegigihan secara sempurna (Gambar 1).

Tabel 1 .

Gambaran Umum Partisipan

\begin{tabular}{lcc}
\hline Karakteristik & Frekuensi & Persentase \\
\hline Jenis Kelamin & & \\
Laki-Laki & 149 & 35,65 \\
Perempuan & 269 & 64,35 \\
Total & $\mathbf{4 1 8}$ & $\mathbf{1 0 0 \%}$ \\
Usia & & \\
16 tahun & 59 & 14,10 \\
17 tahun & 307 & 73,40 \\
18 tahun & 44 & 10,50 \\
$>18$ tahun & 8 & 2,00
\end{tabular}




\begin{tabular}{|c|c|c|c|c|c|}
\hline \multirow{2}{*}{\multicolumn{6}{|c|}{$\begin{array}{l}\text { Total } \\
\text { Pendidikan Ayah }\end{array}$}} \\
\hline & & & & & \\
\hline Pendidikan dasar & 202 & 48,33 & Bebas & 64 & 15,80 \\
\hline Pendidikan & & & Tidak bekerja & 16 & 3,95 \\
\hline menengah & 131 & 31,34 & Lain-lain & 11 & 2,72 \\
\hline Pendidikan tinggi & 72 & 17,22 & Tidak mengisi & 13 & 3,11 \\
\hline Tidak mengisi & 13 & 3,11 & Total & 418 & $100 \%$ \\
\hline Total & 418 & $100 \%$ & Pekerjaan Ibu & & \\
\hline & & & PNS & 20 & 4,78 \\
\hline Karakteristik & Frekuensi & Persentase & Guru & 20 & 4,78 \\
\hline Pendidikan Ibu & & & Pegawai & & \\
\hline Pendidikan dasar & 235 & 56,22 & Swasta/BUMN & 2 & 0,48 \\
\hline Pendidikan & & & Pegawai Usaha & & \\
\hline menengah & 110 & 26,32 & Kecil & 19 & 4,56 \\
\hline Pendidikan tinggi & 64 & 15,31 & Buruh Pabrik & 19 & 4,56 \\
\hline Tidak mengisi & 9 & 2,15 & Petani & 24 & 5,74 \\
\hline Total & 418 & $100 \%$ & Pedagang & 77 & 18,42 \\
\hline Pekerjaan Ayah & & & Asisten Rumah & & \\
\hline PNS & 41 & 10,12 & Tangga & 33 & 7,89 \\
\hline TNI/Polri & 5 & 1,23 & Serabutan/Pekerja & & \\
\hline Guru & 18 & 4,44 & Bebas & 11 & 2,63 \\
\hline Pegawai & & & Tidak bekerja & 173 & 41,38 \\
\hline Swasta/BUMN & 16 & 3,95 & Lain-lain & 11 & 2,63 \\
\hline Pegawai Usaha & & & Tidak mengisi & 9 & 2,15 \\
\hline Kecil & 15 & 3,70 & Total & 418 & $100 \%$ \\
\hline
\end{tabular}

Tabel 2

Uji Mediasi

\begin{tabular}{lcccccc}
\hline & $\mathbf{B}$ & $\mathbf{S . E}$ & $\boldsymbol{\beta}$ & $\mathbf{t}$ & $\mathbf{R}^{2}$ & $\mathbf{F}$ \\
\hline Growth Mindset_School well-being & 0.509 & 0.135 & 0.182 & $3.784^{* *}$ & 0.033 & $14.317^{* *}$ \\
Growth Mindset_Kegigihan & 0.445 & 0.051 & 0.392 & $8.683^{* *}$ & 0.153 & $75.386^{* *}$ \\
Growth Mindset_School well-being & 0.073 & 0.136 & 0.026 & 0.538 & & \\
melalui Kegigihan & 0.980 & 0.120 & 0.399 & $8.196^{* *}$ & 0.168 & $41.885^{* *}$ \\
\end{tabular}

$* * \mathrm{p}<0.001$

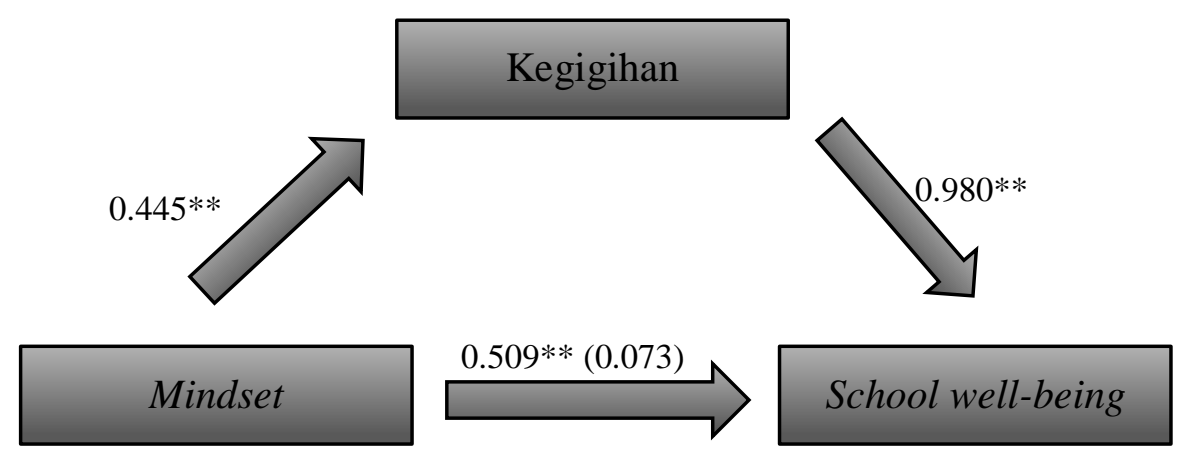

Gambar 1. Kegigihan sebagai mediator antara mindset dan school well-being 


\section{DISKUSI}

Penelitian ini bertujuan untuk mengkaji hubungan growth mindset, school wellbeing, dan kegigihan pada siswa sekolah menengah. Hasil penelitian ini menunjukkan bahwa hubungan growth mindset dan school well-being, growth mindset dan kegigihan, maupun kegigihan dan school well-being ketiganya memiliki hubungan positif yang signifikan. Artinya, semakin tinggi tingkat growth mindset siswa, semakin tinggi pula tingkat school well-being siswa. Semakin tinggi tingkat growth mindset siswa, semakin tinggi pula kegigihan siswa. Semakin besar kegigihan siswa, semakin tinggi tingkat school wellbeing siswa.

Hasil penelitian ini juga menjawab pertanyaan utama peneliti bahwa pengaruh growth mindset terhadap school well-being pada siswa sekolah menengah dimediasi oleh kegigihan. Dapat dikatakan, growth mindset memprediksi tingkat kegigihan yang lebih tinggi, yang lebih lanjut hal tersebut berdampak positif pada school well-being siswa. Adanya hasil penelitian ini melengkapi temuan-temuan sebelumnya yang telah mempelajari ketiga variabel tersebut, diantaranya: a) growth mindset memprediksi well-being siswa melalui resiliensi (Zeng, Hou, \& Peng, 2016); b) growth mindset berpengaruh pada kegigihan seseorang untuk belajar dan bersekolah (Chrisantiana \& Sembiring, 2017; Renaud-Dubé, Guay, Talbot, Taylor, \& Koestner, 2015); c) growth mindset, motivasi belajar, dan kegigihan saling berhubungan. Dengan memiliki growth mindset memprediksi tingginya derajat otonomi dalam motivasi belajar siswa sehingga berdampak positif pada kegigihan siswa (Zhao, Kong, Du, Yang, \& Wang, 2018); d) growth mindset berhubungan dengan happiness pada siswa (Chan, 2012), sementara e) fixed mindset berhubungan dengan afek negatif pada siswa (King, 2017); f) kegigihan memprediksi wellbeing melalui pemenuhan kebutuhan dasar otonomi dan kompetensi (Jin \& Kim, 2017).

Berdasarkan hasil analisis regresi, menunjukkan bahwa kegigihan sebagai memediasi hubungan antara growth mindset dan school well-being secara sempurna. Artinya, agar memiliki school well-being yang baik, siswa dengan growth mindset perlu memiliki kegigihan. Seorang siswa yang percaya bahwa inteligensinya bersifat plastis dan kemampuan yang dimilikinya dapat terus berkembang (memiliki growth mindset), akan memiliki penilaian positif terhadap sekolah. Hal ini terjadi karena ia berusaha secara gigih dan tetap fokus mencapai cita-cita atau tujuannya. Hal ini membuatnya tidak menyerah dengan kondisi yang menantang ataupun berbagai kondisi sulit yang ditemui di sekolah. Ia akan tetap bisa merasa bahagia dan bersikap positif pada sekolahnya (memiliki school well-being yang baik) dibanding siswa yang berpikir bahwa inteligensi dan kemampuannya tidak dapat berkembang (memiliki fixed mindset). Yang perlu ditegaskan adalah memiliki growth mindset saja tidak cukup untuk membuat siswa memiliki school well-being yang baik karena butuh kegigihan sebagai perantara. Artinya, belief harus dibarengi dengan usaha yang sungguh-sungguh agar school well-being dapat tercapai.

Hasil temuan ini juga memberikan implikasi praktis. Agar siswa memiliki school well-being, praktisi pendidikan, psikolog pendidikan, ataupun pihak sekolah dapat mempertimbangkan growth mindset dan kegigihan sebagai sasaran intervensi. Sebagai contoh, intervensi growth mindset 
yang dilakukan (Paunesku, Dweck, Romero, Smith, Yeager, \& Walton, 2015) kepada siswa SMA di Amerika menunjukkan bahwa intervensi growth mindset berpengaruh terhadap perubahan belief siswa mengenai tugas-tugas akademik, sebagai suatu aktivitas yang berguna untuk sarana belajar dan berkembang. Dengan mengajarkan growth mindset, belief siswa terkait kemampuan dan inteligensinya akan dapat berubah sehingga hal tersebut dapat mengembangkan kegigihan siswa.

Intervensi growth mindset perlu dibarengi dengan kegigihan untuk mendukung peningkatan school well-being siswa. Kegigihan merupakan usaha yang terfokus dalam mencapai kesuksesan dari suatu tugas meski harus menghadapi berbagai rintangan dan adanya kemampuan untuk mengatasi rintangan tersebut (Sturman \& Zappala-Piemme, 2017). Kegigihan dapat menjadi karakter dalam diri siswa yang membantunya mengatasi kesulitan dan situasi krisis yang dialami (Arya \& Lal, 2018). Menurut Duckworth (2016), kegigihan dapat ditumbuhkan dan dikembangkan pada seseorang melalui beberapa hal, salah satunya melalui lingkungan (Duckworth, 2016). Hal ini memberi kesempatan pada sekolah untuk dapat membentuk karakter kegigihan pada siswa. Misalnya melalui aturan, aktivitas, dan kebijakan yang dapat merangsang tumbuh kembang kegigihan.

Dengan banyaknya waktu yang dihabiskan siswa di sekolah, sekolah dapat menjadi institusi strategis pencetak generasi muda yang berkualitas. Selain melalui peningkatan kemampuan kognitif, juga melalui kemampuan non-kognitif siswa, seperti kegigihan dan growth mindset (Polirstok, 2017). Dengan demikian, sekolah ikut andil menjembatani peningkatan kualitas sumber daya manusia dan kehidupan masyarakat secara luas.

Penelitian mengenai growth mindset, school well-being, dan kegigihan ini memiliki limitasi dan membutuhkan studi lanjut. Partisipan dalam penelitian ini merupakan siswa kelas 12 dari satu daerah Purbalingga saja. Untuk mengetahui dampak secara luas dan generalisasi hasil penelitian, penelitian selanjutnya dapat dilakukan kepada kelas yang lain, jenjang pendidikan yang lain, maupun daerah yang lain. Di luar adanya limitasi tersebut, temuan penting dari penelitian ini adalah kegigihan berperan dalam memediasi growth mindset dan school well-being. Growth mindset akan membantu meningkatkan kegigihan, yang mana hal tersebut akan membantu meningkatkan school well-being.

\section{UCAPAN TERIMA KASIH}

Ucapan terima kasih disampaikan kepada Lembaga Pengelola Dana Keuangan Republik Indonesia (LPDP RI) sebagai sponsor atau pemberi dana utama penelitian ini.

\section{DAFTAR RUJUKAN}

Akbağ, M., \& Ümmet, D. (2017). Predictive Role of Grit and Basic Psychological Needs Satisfaction on Subjective Well-Being for Young Adults. Journal of Education and Practice, 9.

Arya, B., \& Lal, D. S. (2018). Grit and sense of coherence as predictors of well-being. Indian Journal of Positive Psychology, 9(01). https://doi.org/10.15614/ijpp.v9i01.117 66

Bask, M. \& Salmela-Aro, K. (2012). Burned out to drop out: Exploring the relationship between school burnout and 
142 I Jurnal Psikologi Talenta Vol. 4 No. 2

school dropout. Eur $J$ Psychol Education 2013: 28:511-528. DOI $10.1007 / \mathrm{s} 10212-012-0126-5$

Blackwell, K. L., Trzesniewski, K. H., \& Dweck, C. S. (2007). Implicit theories of intelligence predict achievement across an adolescent transition: A longitudinal study and an intervention. Child Development, 78(1), 246-263

Chan, D. W. (2012). Life satisfaction, happiness, and the growth mindset of healthy and unhealthy perfectionists among Hong Kong Chinese gifted students. Roeper Review, 34(4), 224 233.

https://doi.org/10.1080/02783193.2012. 715333

Chrisantiana, T. G., \& Sembiring, T. (2017). Pengaruh Growth dan Fixed Mindset terhadap Grit pada Mahasiswa Fakultas Psikologi Universitas " $\mathrm{X}$ " Bandung. Humanitas (Jurnal Psikologi), 1(2), 133. https://doi.org/10.28932/humanitas.v1i2 .422

Diener, E., Suh, E. M., Lucas, R. E., \& Smith, H. L. (1999). Subjective wellbeing: Three decades of progress. Psychological Bulletin, 125, 276-302. Retrieved from http://internal.psychology.illinois.edu

Duckworth, A. L., \& Quinn, P. D. (2009). Development and Validation of the Short Grit Scale (Grit-S). Journal of Personality Assessment, 91(2), 166174.

https://doi.org/10.1080/0022389080263 4290

Duckworth, A. L., Peterson, C., Matthews, M. D., \& Kelly, D. R. (2007). Grit: Perseverance and passion for long term goals. Journal of Personality and Social Psychology, 92, 1087-1101.

Duckworth, A. (2016). Grit: Kekuatan Passion dan Kegigihan. Jakarta: Gramedia
Peran Kegigihan dalam Hubungan Growth Mindset

Dweck, C. S., Walton, G. M., \& Cohen, G. L. (2014). Academic Tenacity: Mindsets and Skills that Promote Long-Term Learning. Bill \& Melinda Gates Foundation. Retrieved from https://eric.ed.gov/?id=ED576649

Evans, P., Martin, A. J., \& Ivcevic, Z. (2018). Personality, coping, and school well-being: an investigation of high school students. Social Psychology of Education.

https://doi.org/10.1007/s11218-0189456-8

Gravetter, F. J., \& Forzano, L. B. (2012). Research Methods for the Behavioral Sciences (4th ed.). Belmont, CA: Wadsworth.

Hochanadel, A., \& Finamore, D. (2015). Fixed and growth mindset in education and how grit helps students persist in the face of adversity. Journal of International Education Research (JIER), $\quad 11(1), \quad 47$. https://doi.org/10.19030/jier.v11i1.9099

Hossaini, S. S., Boogar, I., \& Najafi, M. (2017). Predicting General Well-Being Based on Resiliency Protective Factors and Demographics in Adolescents: The Mediating Role of Emotional Stability. International Journal of School Health, 4(2).

https://doi.org/10.5812/intjsh.44811

Jach, H. K., Sun, J., Loton, D., Chin, T.-C., \& Waters, L. E. (2017). Strengths and subjective wellbeing in adolescence: strength-based parenting and the moderating effect of mindset. Journal of Happiness Studies. https://doi.org/10.1007/s10902-0169841-y

Jin, B., \& Kim, J. (2017). Grit, basic needs satisfaction, and subjective well-being. Journal of Individual Differences, $38(1)$, 29-35. https://doi.org/10.1027/16140001/a000219 
Konu, A, \& Rimpelä, M. 2002. Well-being in school: A conceptual model. Health Promotion International, 17(1), 79-87.

King, R. B. (2017). A fixed mindset leads to negative affect: The relations between implicit theories of intelligence and subjective well-being. Zeitschrift Für Psychologie, 225(2), 137-145. https://doi.org/10.1027/21512604/a000290

Lampropoulou, A. (2018). Personality, school, and family: What is their role in adolescents' subjective well-being. Journal of Adolescence, 67, 12-21. https://doi.org/10.1016/j.adolescence.20 18.05.013

Lester, L., \& Cross, D. (2015). The relationship between school climate and mental and emotional wellbeing over the transition from primary to secondary school. Psychology of Well-Being, 5(1). https://doi.org/10.1186/s13612-0150037-8

Nanda, A., \& Widodo, P. B. (2015). Efikasi diri ditinjau dari school well-being pada siswa sekolah menengah kejuruan di Semarang, Jurnal Empati, 4, 6.

Papalia D.E., Olds, S.W, \& Feldman, R.D. (2009). Human Development. New York: Mc-Graw Hill

Paunesku, D., Walton, G. M., Romero, C., Smith, E. N., Yeager, D. S., \& Dweck, C. S. (2015). Mind-set interventions are a scalable treatment for academic underachievement. Psychological Science, 26(6), 784-793. https://doi.org/10.1177/0956797615571 017

Polirstok, S. (2017). Strategies to improve academic achievement in secondary school students: Perspectives on grit and mindset. SAGE Open, 7(4), 215824401774511. https://doi.org/10.1177/2158244017745 111
Renaud-Dubé, A., Guay, F., Talbot, D., Taylor, G., \& Koestner, R. (2015). The relations between implicit intelligence beliefs, autonomous academic motivation, and school persistence intentions: a mediation model. Social Psychology of Education, 18(2), 255272. https://doi.org/10.1007/s11218014-9288-0

Rosyadi, A. K., \& Laksmiwati, H. (2018). Hubungan antara grit dengan subjective well-being pada mahasiswa psikologi Universitas Negeri Surabaya angkatan 2017. Jurnal Psikologi, 05, 6.

Santrock, J. W. (2011). Children 10th edition. New York: McGraw-Hill Company

Shaari, Z.H., Amar, A., Harun, A. B., \& Zainol, M.R. (2017). Exploring the mindsets and well-being of rural secondary school students in Perak, Malaysia. Global Business and Management Research: An International Journal, 9(1), 728-737

Stoffel, J. M., \& Cain, J. (2018). Review of grit and resilience literature within health professions education. American Journal of Pharmaceutical Education, 82(2). https://doi.org/10.5688/ajpe6150

Sturman, E. D., \& Zappala-Piemme, K. (2017). Development of the grit scale for children and adults and its relation to student efficacy, test anxiety, and academic performance. Learning and Individual Differences, 59, 1-10. https://doi.org/10.1016/j.lindif.2017.08. 004

Wijayanti, P. A. K., \& Sulistiobudi, R. A. (2018). Peer relation sebagai prediktor utama school well-being siswa sekolah dasar. Jurnal Psikologi, 17(1), 56. https://doi.org/10.14710/jp.17.1.56-67

Zeng, G., Hou, H., \& Peng, K. (2016). Effect of growth mindset on school engagement and psychological wellbeing of Chinese primary and middle 
school students: The mediating role of resilience. Frontiers in Psychology, 7. https://doi.org/10.3389/fpsyg.2016.0187 3

Zhao, Y., Niu, G., Hou, H., Zeng, G., Xu, L., Peng, K., \& Yu, F. (2018). From growth mindset to grit in Chinese schools: The mediating roles of learning motivations. Frontiers in Psychology, 9. https://doi.org/10.3389/fpsyg.2018.0200 7 